\title{
AKTIVITAS ANALGESIK EKSTRAK ETANOL BULU BABI (ECHINOMETRA MATHAEI) PADA MENCIT PUTIH JANTAN
}

\author{
(Analgesic Activity of Sea Urchin Ethanol Extract (Echinometra mathaei) in white \\ male mice)
}

\author{
Lestiono, Angelica Kresnamurti, Effendi Rahmad, Muhammad Riko Ansyori \\ Prodi Farmasi, Fakultas Kedokteran, Universitas Hang Tuah, Jl. Arief Rahman Hakim 150 \\ Surabaya \\ Email : lestionoaptuht@gmail.com \\ angelica.kresnamurti@hangtuah.ac.id
}

\begin{abstract}
Sea urchin (Echinometra mathaei) is a potential marine resourches that had not been explored widely. It has flavonoid, triterpenoid, alkaloid, saponin compound with high antioxidant activity. Antioxidant activity and flavonoid compound were potentially correlated with analgesic activity. This study aimed to examine e the potential of Echinometra mathaei as an analgesic in white male mice that were induced by acetic acid to produce peripheral pain in vivo (streatching in mice) with writhing test method. The amount of stretching was observed for 1 hour after administration of ethanol extract of Echinometra mathaei orally. Balb/c white mice which devided into 6 groups randomlly, as negative control group, a group that induced acetic acid 1\%, Asetosal group with dose of $65 \mathrm{mg} / \mathrm{kgBW}$, and Echinometra Mathaei groups with the dose of $100 \mathrm{mg} / \mathrm{kgBW}, 200 \mathrm{mg} / \mathrm{kgBW}$, and $400 \mathrm{mg} / \mathrm{kgBW}$. The results of this study showed that all dosage of Echinometra mathaei decrease the peripheral compared to negative control $(\mathrm{P}, 0.05)$. The percentage inhibition of pain at $200 \mathrm{mg} / \mathrm{kgBW}(72.59 \%)$ was the highest among other doses was significant different from asetosal group (52.53\%). This research concluded that Echinometra mathaei has the analgesic activity to inhibit peripheral pain .
\end{abstract}

Keywords: Echinometra mathaei, ethanol extract, analgesic, mice, writhing test

\section{PENDAHULUAN}

Secara geografi Indonesia merupakan negara kepulauan dengan kekayaan sumber daya alam laut yang berpotensi untuk dimanfaatkan secara lestari. Bulu babi merupakan salah satu jenis biota perairan laut yang berasal dari filum Echinodermata, penyebaran bulu babi terlihat hampir di seluruh zona perairan. Jenis Bulu babi di Indonesia sangat beragam dengan famili yang berbeda, contohnya bulu babi yang ditemukan di perairan pantai di Bali terdapat 12 jenis Bulu babi dengan 6 famili yang berbeda seperti jenis Clypeaster sp., Astropyga radiata, Diadema palmeri, Diadema savignyi, Diadema setosum, Echinothrix calamaris, Echinometra mathaei, Heterocentrotus sp., Maretia planulata, Temnopleurus sp., Toxopneustes sp. dan Tripneustes gratilla (Wulandewi et al., 2015). Echinometra mathaei (EM) merupakan salah satu jenis bulu babi di Indonesia yang paling banyak ditemukan, dengan daerah penyebaran di seluruh zona terumbu karang (Zakaria, 2013).
Bulu babi memiliki cangkang yang keras dan bagian dalamnya bersisi lima simetris. Cangkang dari jenis bulu babi tertentu dilapisi oleh pigmen cairan hitam yang stabil. Kandungan dalam cangkang bulu babi telah diketahui sampai saat ini adalah polihidroksi dan apelasterosida A dan B (Hadinoto et al., 2016).

Menurut Soleimani (2017), esktrak etanol bulu babi jenis Echinometra mathaei mempunyai sifat sebagai anti-inflamasi yang serupa dengan aspirin, dimana aspirin tergolong dalam NSAID yang dapat bekerja sebagai anti-inflamasi, analgesik dan antipiretik. Aspirin dengan anti inflamasi bekerja dengan cara menghambat aktivitas enzim cyclooxygenase-2 (COX-2) yang menghambat pembentukan prostaglandin (PG) yang menyebabkan peradangan, pembengkakan, nyeri dan demam (Vane, 2003). Berdasarkan penelitian Soleimani, maka tujuan dari penelitian ini adalah menguji aktivitas analgesik ekstrak etanol Echinometra 
mathaei dalam menghambat nyeri perifer karena induksi asam asetat dengan metode writhing test.

\section{II.TINJAUAN PUSTAKA}

Bulu babi termasuk dalam anggota kelas Echinoidea. Bulu babi merupakan hewan laut yang 95\% permukaan tubuhnya terdiri dari duri-duri yang dapat digerakkan (Hilda, 2012). Hewan ini dapat ditemukan mulai dari perairan laut tropis hingga kutub. Bulu babi berperan penting sebagai salah satu rantai makanan di pesisir pantai, terutama di ekosistem terumbu karang. Hal ini karena terumbu karang berperan sebagai tempat berlindung dan tempat pakan bagi fauna Echinodermata. Secara ekologi fauna Echinodermata berperan sangat penting dalam ekosistem terumbu karang, terutama dalam rantai makanan (food chains), karena biota tersebut umumnya sebagai pemakan detritus dan predator (Suwartimah et al, 2017). Salah satu jenis Echinodermata yang paling banyak ditemukan adalah spesies Echinometra mathaei.

Bulu babi sering dimanfaatkan masyarakat pesisir sebagai makanan, bagian tubuh yang sering dikonsumsi adalah gonad atau telurnya. Gonad bulu babi mengandung asam amino yang cukup lengkap sebagai pemacu pertumbuhan dan kesehatan (Dincer et al, 2010). Gonad bulu babi dapat dijadikan sebagai sumber pangan alternatif karena mengandung 28 macam asam amino, vitamin B kompleks, vitamin A, mineral, asam lemak omega-3, dan omega-6, sementara cangkangnya memiliki potensi sebagai antikanker, antitumor dan antimikroba (Aprillia, Pringgenies, \& Yudiati, 2012).

Bulu babi memiliki cangkang yang keras dan bagian dalamnya terdiri dari lima simetris. Cangkang dari jenis bulu babi tertentu dilapisi oleh pigmen cairan hitam yang stabil (Hadinoto et.al., 2016). Sebagai antimikroba, cangkang bulu babi memiliki kandungan senyawa bioaktif antara lain, serotonin, glikosida, steroid, bahan cholinergic, dan bradykininlike substances (Dahl, Jebson \& Louis, 2010).

Abubakar et al., (2012) menyatakan bahwa toksin yang dihasilkan oleh organisme bulu babi dapat dimanfaatkan dalam bidang pengobatan yang berpotensi untuk dimanfaatkan sebagai antibiotik tipe baru untuk dikembangkan dalam bidang farmasi karena mengandung senyawa bioaktif. Li et al (2010), melaporkan bahwa 43\% aktivitas antimikroba berasal dari 83 spesies Echinodermata. Penelitian lainnya yang dilaporkan oleh Hadinoto et al (2016), menyatakan bahwa hasil ekstrak cangkang bulu babi jenis Diadema setosum dengan pelarut metanol menunjukkan memiliki kemampuan sebagai antibakteri. Senyawa bioaktif dari ekstrak metanol cangkang bulu babi dari jenis Salmacis virgulata yaitu polyhydroxy napthoquinone diketahui berpotensi sebagai antibakteri maupun antioksidan (Shankarlal, Prabu \& Natarajan, 2011).

Penelitian tentang kandungan lemak dan asam lemak dari gonad bulu babi menarik perhatian dari beberapa kelompok peneliti karena bulu babi memiliki kandungan lipid aktif, terutama omega-3, omega-6, dan omega-9 (Long, 2005). Selain asam lemak bulu babi juga memiliki metabolit sekunder, yaitu napthoquinone. Naphthoquinone merupakan metabolit sekunder yang paling sering diteliti oleh ilmuwan karena memiliki efek anti radikal bebas. Beberapa penelitian melaporkan bahwa napthoquinone memiliki potensi sebagai antialergi, antidiabetes, antihipertensi, antiinflamasi, kardioprotektif, dan hipokolestrolemia (Shikov, 2018).

Menurut Soleimani (2017), esktrak metanol bulu babi mempunyai sifat sebagai anti inflamasi yang serupa dengan aspirin. Obat-obat anti inflamasi (NSAID) menghambat aktivitas enzim cyclooxygenase-2 (COX-2) yang menghambat pembentukan prostaglandin (PG) yang menyebabkan peradangan, pembengkakan, nyeri dan demam (Vane, 2003).

\section{Metode Penelitian}

Penelitian ini adalah penelitian true experimental dengan menggunakan post test grup design.

\subsection{Alat dan Bahan penelitian}

Alat yang digunakan dalam penelitian ini antara lain Rotavapor, alat gelas, timbangan analitik, perlengkapan uji pada mencit (kandang, sonde oral mencit, spuit injeksi $1 \mathrm{ml}$ ).

Bahan uji yang digunakan adalah gonad dan cangkang dari Echinometra mathaei yang dikoleksi dari pulau We, Pantai Sabang, Banda Aceh yang telah dideterminasi pada Unit Layanan Biologi FST Universitas Airlangga pada 13 Agustus 2019. 
Echinometra mathaei yang didapatkan dari laut Pulau We, Sabang-Aceh, telah disortasi, dikeringkan, dan diekstraksi secara maserasi dengan etanol $70 \%$. Bahan kimia yang digunakan adalah asetosal sebagai pembanding, asam asetat $1 \%$, aquadest steril, dan $\mathrm{CMC} \mathrm{Na}$ sebagai suspending agent. Asetosal digunakan pada kontrol positif pada penelitian ini karena asetosal mempunyai efek analgesik yang bekerja secara perifer, sesuai jenis induksi nyeri yang digunakan (asam asetat 1\%).

Bahan kimia untuk skrining fitokimia dibutuhkan etanol 50\%, 70\%, 96\%, $\mathrm{HCl} 2 \mathrm{~N}$, pereaksi dragendroff, $\mathrm{FeCl}_{3}$, aquadest, serbuk magnesium, $\mathrm{CuSO}_{4}$, plat $\mathrm{KLT}$, butanol p.a, asam asetat glasial p.a, kloroform p.a, pereaksi Liberman-Bucard, n-Heksan p.a, etil asetat p.a, KOH $10 \%$.

\subsection{Hewan coba dan pertimbangan etik}

Penelitian ini menggunakan mencit putih jantan galur balb/C. sejumlah 30 ekor yang terbagi secara random dalam 6 kelompok uji masing-masing terdiri dari 5 ekor mencit. Mencit usia dewasa muda 2-3 bulan, berat badan 20-30 gram, dengan aktivitas normal, sehat, dan tidak tampak kecacatan pada tubuhnya digunakan dalam penelitian ini. Mencit diadaptasikan dahulu pada lingkungan laboratorium selama 7 hari sebelum digunakan untuk penelitian pada suhu ruang $\pm 25^{\circ} \mathrm{C}, 12$ jam terang dan 12 jam gelap. Pemberian makanan adalah pakan standar dan minum ad libitum.

Penelitian ini telah lolos uji etik penelitian kesehatan dengan sertifikasi KEPK FKG Universitas Hang Tuah nomor : Sket/036/KEPKFKGUHT/XI/2019.

\subsection{Uji skrining fitokimia}

Uji skrining fitokimia dilakukan seperti di bawah ini: a. Uji Alkaloid

Ekstrak Echinometra mathaei dilarutkan dengan $5 \mathrm{~mL} \mathrm{HCl} 2 \mathrm{~N}$. Larutan yang didapat kemudian dibagi 3 tabung reaksi. Tabung pertama digunakan sebagai blanko, tabung kedua ditambahkan pereaksi Dragendroff sebanyak 3 tetes, dan tabung ketiga ditambahkan pereaksi Mayer sebanyak
3 tetes. Terbentuknya endapan jingga pada tabung kedua dan endapan putih hingga kekuningan pada tabung ketiga menunjukkan adanya alkaloid (Jones dan Kinghorn, 2006).

b. Uji Tanin

Ekstrak ditambahkan dengan $1 \mathrm{~mL}$ larutan $\mathrm{Fe}(\mathrm{III})$ klorida 10\%. Jika terbentuk warna biru tua, biru kehitaman atau hitam kehijauan menunjukkan adanya senyawa polifenol dan tanin (Jones dan Kinghorn, 2006).

c. Uji Saponin

Ekstrak ditambahkan dengan $10 \mathrm{~mL}$ air panas kemudian didinginkan, dikocok kuat selama 10 detik. Terbentuk buih yang mantap selama tidak kurang 10 menit setinggi 1-10 $\mathrm{cm}$. Pada penambahan $\mathrm{HCl} 2 \mathrm{~N}$, buih akan hilang (Depkes RI, 1995).

d. Uji Flavonoid

Ekstrak sebanyak $2 \mathrm{~mL}$ dipanaskan kemudian ditambahkan etanol kedalam larutan ditambahkan serbuk magnesium dan ditambahkan HCl. Terbentuk larutan bewarna merah menunjukkan adanya flavonoid (Lumbessy dkk, 2013).

\subsection{Uji aktivitas analgetik}

Total 30 ekor mencit digunakan dalam penelitian ini berdasarkan rumus Federer dengan 6 jenis kelompok uji, yang dibagi dalam 6 kelompok uji, setiap kelompok terdiri dari 5 ekor mencit. Kelompok I adalah kelompok kontrol tanpa induksi asam asetat (CMC Na 0,5\% p.o), kelompok II, III, IV, V, VI diberikan induksi asam asetat $1 \%$, secara intraperitoneal dan diberikan sediaan uji berturutturut adalah $\mathrm{CMC} \mathrm{Na} 0,5 \%$, asetosal $65 \mathrm{mg} / \mathrm{KgBB}$, ekstrak etanol Echinometra dosis $100 \mathrm{mg} / \mathrm{KgBB}, 200$ $\mathrm{mg} / \mathrm{KgBB}$, dan $400 \mathrm{mg} / \mathrm{KgBB}$. Pemilihan dosis berdasarkan efektivitas ekstrak Echinometra mathaei pada penelitian antipiretik sebelumnya

Percobaan ini menggunakan metode Writhing Test / Metode Geliat, dengan pemberian induksi asam asetat $1 \%$ (indikator nyeri) kepada mencit yang akan menimbulkan geliat (Writhing). Respon mencit diamati setelah 5 menit induksi asam asetat, jumlah geliat mencit diamati setiap 5 menit selama 60 menit. 
Jumlah geliat diakumulasikan dan dihitung presentase hambatan nyeri untuk setiap kelompok.

\subsection{Analisis statistik}

Data jumlah kumulatif geliat mencit masingmasing kelompok uji dalam waktu 1 jam, dianalisis dengan SPSS versi 22.0 secara statistik parametrik dengan one way anova dan dilanjutkan Kruskalwallis test untuk mengetahui apakah terdapat perbedaan antar kelompok hewan coba.

\section{HASIL DAN PEMBAHASAN}

Pada metode ini dilakukan metode ekstraksi menggunakan maserasi dipilih karena maserasi merupakan cara ekstraksi sederhana yang mudah dilakukan dengan cara merendam bahan dalam pelarut selama 3 hari pada temperature kamar dan terlindung dari cahaya. Etanol merupakan pelarut polar yang banyak digunakan untuk mengekstrak komponen polar suatu bahan alam dan dikenal sebagai pelarut universal. Komponen polar dari suatu bahan alam dalam ekstrak dapat diambil dengan Teknik ekstraksi melalui proses pemisahan (Santana, et al., 2009). Menurut Sudarmadji (2003) etanol dapat mengekstrak senyawa aktif yang lebih banyak dibandingkan jenis pelarut organic lainnya. Etanol mempunyai titik didih yang rendah yaitu 79 ${ }^{\circ} \mathrm{C}$ sehingga memerlukan panas yang lebih sedikit untuk proses pemekatan.

Pada penelitian ini juga dilakukan skrining fitokimia untuk mengetahui kandungan metabolit sekunder dari ekstrak etanol $70 \%$ Echinometra mathaei. Hasil skrining fitokimia menunjukkan kandungan triterpenoid, flavonoid, alkaloid, saponin, dan tannin. Hal ini sesuai dengan penelitian Karmilah \& Esti (2019) untuk kandungan saponin, dan kandungan naphtoquinone yang merupakan golongan dari flavonoida sesuai dengan penelitian Soleimani (2016).

Tabel 1. Hasil Skrining Fitokimia Ekstrak Etanol 70\%

\begin{tabular}{|c|c|l|l|l|}
\multicolumn{6}{|c|}{ Echinometra mathaei } \\
\hline No & $\begin{array}{c}\text { Uji } \\
\text { Fitokimia }\end{array}$ & Pereaksi & $\begin{array}{c}\text { Perubahan } \\
\text { Warna }\end{array}$ & $\begin{array}{l}\text { Keterang } \\
\text { an }\end{array}$ \\
\hline 1 & $\begin{array}{l}\text { Triterperpe } \\
\text { noid/steorid }\end{array}$ & $\begin{array}{l}\text { Lieberman- } \\
\text { Burchard }\end{array}$ & $\begin{array}{l}\text { Kuning menjadi } \\
\text { merah ungu }\end{array}$ & $\begin{array}{l}\text { Triterpe } \\
\text { noid (+) }\end{array}$ \\
\hline 2 & Flavonoid & Wilstater & $\begin{array}{l}\text { Kuning menjadi } \\
\text { kuning pekat }\end{array}$ & $\begin{array}{l}\text { Flavonoi } \\
\text { d (+) }\end{array}$ \\
\hline
\end{tabular}

\begin{tabular}{|c|l|l|l|l|}
\hline 3 & Alkaloid & $\begin{array}{l}\text { Wagner } \\
\text { Meyer } \\
\text { Dragendroff }\end{array}$ & $\begin{array}{l}\text { Terdapat } \\
\text { endapan cokelat } \\
\text { Terdapat } \\
\text { endapan putih } \\
\text { Terjadi bercak } \\
\text { coklat }\end{array}$ & $\begin{array}{l}\text { Alkaloid } \\
(+)\end{array}$ \\
\hline 4 & Saponin & $\begin{array}{l}\text { Akuades, } \\
\text { dipanakan } \\
\text { kocok }\end{array}$ & $\begin{array}{l}\text { Timbul busa } \\
\text { selama 30 } \\
\text { menit }\end{array}$ & $\begin{array}{l}\text { Saponin } \\
(+)\end{array}$ \\
\hline 5 & Tanin & $\mathrm{FeCl}_{3}$ & $\begin{array}{l}\text { Terdapat } \\
\text { endapan }\end{array}$ & $\begin{array}{l}\text { Tanin } \\
(+)\end{array}$ \\
\hline
\end{tabular}

Pemberian induksi asam asetat secara intraperitoneal dapat memicu rangsangan nyeri secara fisiologis secara perifer dengan merangsang pelepasan neurotransmitter nyeri seperti prostaglandin, histamin, dan leukotrien sebagai hasil pelepasan asam arakidonat bebas dari jaringan fosfolipid melalui COX-2. Respon nyeri tampak nyata melalui gerakan stretching atau geliat mencit dengan menarik kedua kaki ke depan dan belakang, sehingga perut menempel pada lantai (Mohan et.al., 2012).

Pada penelitian ini respon geliat secara nyata tampak pada tingginya jumlah geliat kelompok induksi asam asetat, berbeda nyata dibandingkan kelompok kontrol yang diberikan induksi aquadest steril i.p tidak menunjukkan geliat (tabel 2.).

Tabel 2. Rata-rata jumlah akumulasi geliat mencit selama 60 menit tiap kelompok uji

\begin{tabular}{|c|c|}
\hline Kelompok & $\begin{array}{c}\text { Jumlah Rata-rata geliat mencit } \\
\pm \mathrm{SD}\end{array}$ \\
\hline $\begin{array}{c}\text { Kelompok kontrol } \\
\text { Asam asetat } 1 \%\end{array}$ & $122,6 \pm 32,08$ \\
\hline Asetosal $65 \mathrm{mg}$ & $58,2 \pm 30,47$ \\
\hline Ekstrak 100mg & $89,8 \pm 10,64$ \\
\hline Ekstrak 200mg & $33,6 \pm 18,42$ \\
\hline Ekstrak 400mg & $76,8 \pm 41,80$ \\
\hline
\end{tabular}

Data hasil rata-rata geliat mencit yang didapatkan, dianalisis dengan menggunakan SPSS versi 22. Dan dilakukan uji normalitas dan homogenitas menggunakan Kolmogorov Smirnov. Hasil menunjukkan bahwa data yang didapatkan dalam penelitian ini bersifat normal dan tidak homogen, sehingga dilanjutkan dengan uji non parametrik berupa yaitu Krustal-Wallis dan dilanjutkan dengan Post Hoc Mann-Whitney untuk mengamati apakah terdapat perbedaan bermakna antar kelompok uji.

Berdasarkan uji Mann-Whitney diketahui 
bahwa pemberian asetosal mempunyai perbedaan bermakna dengan pemberian ekstrak Echinometra mathaei $200 \mathrm{mg} / \mathrm{KgBB}$. Peningkatan dosis ekstrak Echinometra mathaei $100 \mathrm{mg} / \mathrm{KgBB}$ dengan 200 $\mathrm{mg} / \mathrm{KgBB}$ menunjukkan perbedaan bermakna, sedangkan peningkatan dosis $200 \mathrm{mg} / \mathrm{kgBB}$ dengan $400 \mathrm{mg} / \mathrm{kgBB}$ tidak terdapat perbedaan secara tidak bermakna.

Tabel 3. Persen proteksi nyeri setiap kelompok uji

\begin{tabular}{|l|c|}
\hline Kelompok & \% Proteksi nyeri \\
\hline Asam asetat $1 \%$ & 0 \\
\hline Asetosal & 52,53 \\
\hline Ekstrak $100 \mathrm{mg}$ & 26,75 \\
\hline Ekstrak $200 \mathrm{mg}$ & 72,59 \\
\hline Ekstrak 400mg & 37,36 \\
\hline
\end{tabular}

Data hasil perhitungan persentase proteksi nyeri menujukkan peningkatan dosis Echinometra mathaei $200 \mathrm{mg} / \mathrm{KgBB}$ mempunyai aktivitas analgesik yang tinggi karena potensinya 1,5 kali lebih besar daripada asetosal, sedangkan dosis 100 $\mathrm{mg} / \mathrm{KgBB}$ dan $400 \mathrm{mg} / \mathrm{KgBB}$ menunjukkan aktivitas proteksi nyeri yang lebih rendah dari asetosal.

Peningkatan dosis tidak menunjukkan peningkatan aktivitas pada dosis $200 \mathrm{mg} / \mathrm{KgBB}$ dan $400 \mathrm{mg} / \mathrm{KgBB}$. Hal ini dapat disebabkan karena peningkatan bermacam jenis komponen kandungan ekstrak, dapat berpotensi meningkatkan efek yang tidak diharapkan atau menghambat aktivitas senyawa aktif yang berperan sebagai analgesik.

Kandungan Flavonoid pada ekstrak etanol Echinometra mathaei diperkirakan berhubungan dengan aktivitas analgesik ekstrak. Flavonoid pada ekstrak dapat menghambat degranulasi neutrofil sehingga akan menghambat pengeluaran sitokin, radikal bebas, serta enzim yang berperan dalam peradangan (Mohan et.al., 2012).

Penelitian lanjutan yang dilakukan adalah pengujian aktivitas antiinflamasi ekstrak etanol 70\% Echinometra mathaei.

\section{PENUTUP}

Kesimpulan pada penelitian ini adalah Echinometra mathaei memiliki aktivitas hambatan nyeri secara perifer pada mencit putih jantan yang diinduksi asam asetat $1 \%$, sebesar $26,75 \% ; 72,59 \%$ dan $37,36 \%$ pada dosis berturut-turut $100 \mathrm{mg} / \mathrm{KgBB}$, $200 \mathrm{mg} / \mathrm{KgBB}$, dan $400 \mathrm{mg} / \mathrm{KgBB}$.

Aktivitas analgesik ekstrak dosis 200 menunjukkan proteksi nyeri tertinggi daripada dosis yang lain dengan potensi 1,5 kali lebih besar dari asetosal hal ini diduga berhubungan dengan kandungan flavonoid dan saponin pada Echinometra mathaei.

\section{DAFTAR PUSTAKA}

1. Abubakar L, Wangi C, Uku J, Ndirangu S, 2012, 'Antimicrobial activity of various extracts of the sea urchin Tripneustes gratilla (Echinoidea)', African Journal of Pharmacology and Therapeutics, 1(1):1923.

2. Aprilia H.A, Pringgenies D, \& Yudiati E, 2012, 'Uji Toksisitas Ekstrak Kloroform Cangkang dan Duri Landak Laut (Diadema setosum) Terhadap Mortalitas Nauplius artemia sp', Journal of Marine Research, 1(1), 75-83.

3. Dahl W.J, Jebson P, \& Louis D.S, 2010, 'Sea Urchin Injuries to The Hand: A Case Report and Review of The Literature', The lowa Orthopaedic Journal, 30,153-156.

4. Departemen Kesehatan RI. 1989. Materia Medika Indonesia Edisi IV. Jakarta: Departemen Kesehatan RI.

5. Departemen Kesehatan Republik Indonesia. 2000, "Parameter Standar Umum Ekstrak Tumbuhan Obat", Departemen Kesehatan Republik Indonesia, Jakarta.

6. Dincer T, Cakli S, Kilinc B, \& Tolasa S, 2010, 'Amino Acids and Fatty Acids Composition Content of Fish Sauce', Journal of Animal and Veterinary Advances, 9(2): 311-315.

7. Hadinoto Sugeng, Ignacius D. S, Yessy Siahay, 2016, Kandungan Gizi Bulu Babi (Diadema setosum) dan Potensi Cangkangnya Sebagai Antibakteri, Prosiding Seminar Nasional Lahan Basah. Jilid 1:260-265, viewed 28 Agustus 2019.

8. Hilda AP, Delanis \& Ervia, 2012, 'Uji Toksisitas Ekstrak Kloroform Cangkang dan 
Duri Landak Laut (Diadema setosum) terhadap Mortalitas Nauplius Artemia sp'. Jurnal of Marine Research, Vol. 1, no. 1, hal. 75-83.

9. Jones, W.P., Kinghorn, A.D. (2006). Extraction of Plant Secondary Metabolites. In: Sharker, S.D. Latif Z., Gray A.L, eds. Natural Product Isolation. 2nd edition.

10. Karmilah, Esti, Badia, 2019, 'Pengaruh Bentuk Sediaan Ekstrak Gonad Landak Laut (Diadema setosum) Sebagai Penyembuh Luka Bakar Pada Kelinci (Oryctolagus cuniculus)', Window of Health: Jurnal Kesehatan, Vol. 2. No.1.

11. Li C, Haug T, Stensvåg K, 2010, 'Antimicrobial peptides in echinoderms', Invertebrate Survival Journal, 7:132140.

12. Long $\mathrm{PQ}$, Minh CV, 2005, Lipids and biologically active fatty acids from nature, Science and Technology Publishing House

13. Lumbessy, M., Abidjulu, J., Paendong, J.E. 2013.Uji Total Flavonoid Pada Beberapa Tanaman Obat Tradisional Di Desa Kecamatan Mangoi Timur Kabupaten Kepulauan Sula Maluku Utara. JURNALI FMIPA UNSTRA.

14. Mohan, N., Gulecha, V.S., Aurangbadkar, V.M., Balaraman, R., Austin, A. \& Thirugananasampathan, S. (2009). Analgesic And Anti-Inflammatory Activity of a Polyherbal Formulation (PHF-AROGH). Oriental Pharmacy and Experimental Medicine, 9 (3), 232-237

15. Shankarlal S. K. Prabu, \& E. Natarajan, 2011, 'Antimicrobial and Antioxidant Activity of Purple Sea Urchin Shell (Salmacis virgulata L. Agassiz and Desor
1846)', American-Eurasian Journal of Scientific Research 6, (3): 178-181.

16. Shikov, Alexander N, Olga N. P, Anna S.K, Valery G.M, 2018, 'Naphthoquinone pigments from sea urchins: chemistry and pharmacology'. Saint-Petersburg Institute of Pharmacy, Leningrad region, Vsevolozhsky District, Kuzmolovo P 245

17. Soleimani, Soolmaz, Morteza Yousefzadi, Soheila moein, Hassan Rezadoost, Narges Amrollahi Bioki, 2016, 'Identification and antioxidant of polyhydroxylated naphthoquinone pigments from sea urchin pigments of Echinometra mathaei', Medicinal Chemistry Research, DOI 10.1007/s00044016-1586-y.

18. Suwartimah Ken, Dwi Saniscara Wati, Hadi Endrawati, Retno Hartati, 2017, 'Komposisi Echinodermata Di Rataan Litoral Terumbu Karang Pantai

19. Wulandewi N.L.E, Subagio J.E, Wiryatno Joko, 2015, Identify Species and Density of sea Urchin (Echinoidea) at Sanur and Srangan Beach, Denpasar Bali. Jurnal Simbiosis III (1), 269-280.

20. Zakaria I.J, 2013, Komunitas Bulu Babi (Echinoidea) di Pulau Cingkuak, Pulau Sikuai dan Pulau Setan Sumatera Barat. Prosiding, viewed 26 September 2019, SEMIRATA FMIPA, Universitas Lampung, Lampung

21. Vane, J. R. \& R. M. Botting, 2003, "The mechanism of action of aspirin Thrombosis", Research 110 (2003) 255 - 258. 